\title{
The Role of Microbes in Coffee Fermentation and Their Impact on Coffee Quality
}

\author{
Mesfin Haile (iD) and Won Hee Kang (iD \\ Department of Horticulture and Bio-system Engineering, Kangwon National University, Chuncheon 24341, Republic of Korea \\ Correspondence should be addressed to Won Hee Kang; whkang@kangwon.ac.kr
}

Received 16 November 2018; Revised 3 January 2019; Accepted 1 February 2019; Published 7 March 2019

Academic Editor: Susana Fiszman

Copyright (c) 2019 Mesfin Haile and Won Hee Kang. This is an open access article distributed under the Creative Commons Attribution License, which permits unrestricted use, distribution, and reproduction in any medium, provided the original work is properly cited.

\begin{abstract}
Coffee is one of the most important and widely used commercial crops in the world. After ripe coffee cherries are harvested, coffee must pass through several steps to become (green) raw coffee beans. Commonly, there are three different processing methods used to obtain green coffee beans from coffee cherries, namely, the wet, dry, and semidry methods. Microorganisms (yeasts and bacteria) play a major role in coffee fermentation process by degrading mucilage by producing different enzymes (pectinase), acids, and alcohols. Starter culture development is crucial and is done by selecting microorganisms that have certain characteristics, such as mucilage degradation ability, tolerance to stress during fermentation, the ability to suppress the growth of pathogenic fungi, and a positive impact on the sensory quality of the coffee. Currently, green coffee beans obtained from farms that use any of the above processing methods are fermented with selected microorganisms to improve the flavour and aroma of the coffee. This is the result of a new insight into the development of unique flavoured coffee and into engaging with the coffee market to better benefit. This review gives a comprehensive overview of the fermentation process, microorganisms and starter cultures, and fermentation's impact on coffee quality. Future prospects are also discussed through the incorporation of recent research.
\end{abstract}

\section{Introduction}

Coffee is one of the most widely used nonalcoholic drinks, and its consumption is spreading globally. It is the second most important commodity exchanged in world markets, next to crude oil. Brazil is the leading producer and exporter of Coffea arabica [1], followed by Indonesia, Ethiopia, the Philippines, Mexico, Vietnam, and 40 other countries. People drink coffee to relax and enjoy its diverse flavours and aromas. It has physiological and psychological effects beyond its nutritional benefits. In recent years, an appreciation for quality coffee has lent importance to specialty coffees, which have unique aromas and remarkable flavours. These characteristics are linked to the areas where the coffees are grown and their cultivated genotypes [2]. Some researchers report significant differences among beverages from coffee that is processed using different methods $[3,4]$. It is currently believed that different processing methods induce different metabolic reactions in coffee fruits, which can affect the chemical compositions of the coffee beans and thereby their cupping quality $[5,6]$.

Fermentation is a metabolic process that uses sugar, either in the absence (anaerobic) or presence (aerobic) of oxygen. Coffee fermentation is critical for removing mucilage from parchment coffee. Coffee mucilage contains polysaccharides (pectin), cellulose, and starch. The mucilage can prolong the time needed to dry the coffee beans and, in some cases, also lead to mould development, which reduces the final quality of the coffee. The fermentation process is facilitated by enzymes that naturally occur in the coffee fruit and microflora acquired from the environment.

Microorganisms (yeast, bacteria, and fungi) play a major role in degrading mucilage by producing various enzymes, alcohols, and acids during the fermentation process. There are several commercially available enzymes for coffee fermentation. The earliest was marketed under the trade name Benefax. Later brands have included Pectozyme, 
Cofepec, and Ultrazym, which are mixtures of pectinase, hemicellulose, and cellulose [7]. Current research indicates that coffee fermentation is becoming more popular for producing specialty coffee. Vaast et al. [8] have reported that various physiological changes occur in grains during fermentation, such as decreases in water content and simple sugars and the development of aroma and flavour precursors. Therefore, the purpose of this review is to briefly explain the need for coffee fermentation and its impact on major coffee quality attributes, in company with recent research outcomes. This review will provide a clear understanding of the role of microorganisms in coffee fermentation and can direct future research into commercializing potential starter cultures.

\section{Coffee Fermentation Process}

Fermentation is a chemical process in which complex molecules are broken down into simpler molecules, producing liquid products and gasses (volatile compounds). Coffee fruits are processed by one of three methods immediately after harvesting to allow spontaneous or indigenous fermentation to occur. The three different coffee processing methods are referred to as dry, wet, and semidry. Depending on the processing type, the length of time needed for fermentation varies. The main purpose of the fermentation process in all methods is to remove the mucilage layer, which is rich in polysaccharides (pectin), and to decrease the water content of the coffee beans. However, if carefully managed, fermentation also has a positive impact on the coffee's quality attributes.

Wet processing is largely used for Arabica coffee. Immediately after harvesting, the ripe coffee fruits go through a flotation process to clean debris and remove floaters (lowdensity fruits). The coffee fruit is then pulped, put through a 24- to 48-hour underwater tank fermentation process, and dried until the moisture content reaches $10 \%-12 \%[9,10]$. In dry processing, the coffee fruits are cleaned and floaters are separated immediately after harvesting, and the entire coffee fruits are dried in the sun on platforms and/or on the floor without prior removal of the pulp [11]. Semidry processing is a combination of both methods, in which the coffee fruits are depulped but the fermentation process occurs directly under the sun on a platform [12].

2.1. Composition of Mucilage. Coffee mucilage is a viscous liquid residue produced in the coffee industry that is disposed of without treatment directly into watercourses, causing serious contamination problems. The physical and chemical properties of coffee mucilage vary according to species and variety. Studies have shown that the mucilage/ water ratio increases as altitude increases [13]. Mucilage is composed of water $(84.2 \%)$, protein $(8.9 \%)$, reducing sugar $(4.1 \%)$, pectates $(0.91 \%)$, and ash $(0.7 \%)$ [14]. Knowing these compositions is essential for the understanding of coffee fermentation. The chemical composition and composition of mucilage before and after fermentation are described in Tables 1 and 2, respectively.
TABle 1: Chemical composition, on a wet and dry basis, of coffee mucilage.

\begin{tabular}{lc}
\hline Mucilage components & Chemical composition (\%) \\
\hline Wet basis & \\
Moisture & 85.0 \\
Total carbohydrates & 7.0 \\
Nitrogen & 0.15 \\
Acidity (as citric acid) & 0.08 \\
Alcohol-insoluble compounds & 5.0 \\
Pectin (as galacturonic acid) & 2.6 \\
\hline Dry basis & \\
Pectic substances & 33 \\
Reducing sugars & 30 \\
Nonreducing sugars & 20 \\
Cellulose and ash & 17 \\
\hline
\end{tabular}

Adapted from Schwan and Fleet [7].

TABLE 2: The composition of coffee mucilage before and after complete fermentation.

\begin{tabular}{lcc}
\hline Component & Before fermentation (\%) & After fermentation (\%) \\
\hline Water soluble & 35.3 & 50.7 \\
Lipid & 6.0 & 4.0 \\
Pectin & 47.0 & 36.2 \\
Holocellulose & 9.4 & 8.0 \\
Unaccounted & 2.3 & 1.1 \\
\hline
\end{tabular}

Adapted from Schwan and Fleet [7].

\section{Microbial Enzymes and Starter Cultures for Coffee Fermentation}

3.1. Enzymes Produced during Coffee Fermentation. Previous reports have identified over 50 yeasts and bacterial species that are present during coffee fermentation $[15,16]$. Silva et al. [17] mention that the microorganisms in coffee fermentation contribute to the production of ethanol and lactic, butyric, acetic, and other higher carboxylic acids during the fermentation of pectinaceous sugars. Coughlan and Mayer [18] report that a variety of extracellular enzymes are generated by cellulolytic Bacillus species, which potentially contribute to the breakdown of cellulose and pectin substances that exist in the skin, pulp, and mucilage of coffee cherries [11].

The three most important enzymes produced by microorganisms for degrading pectin substances during coffee fermentation are pectin lyase, polygalacturonase, and pectin methyl esterase. Pectin lyase catalyses pectin degradation by trans-elimination, releasing unsaturated galacturonic acids [19]. Polygalacturonase is the main enzyme involved in coffee fermentation. It catalyses the hydrolysis of $\alpha-1,4$ glycosidic bonds into pectic acid (polygalacturonic acid) [20]. Pectin methyl esterase is responsible for the deesterification of the methoxyl group of the pectin, forming pectic acid and methanol [21].

3.2. Starter Cultures for Coffee Fermentation. A starter culture is a microbiological culture that accelerates the fermentation process. In the food fermentation industry, 
starter cultures are widely known for use in cheese, yogurt, beer, and wine $[22,23]$. The use of starter culture in a controlled coffee fermentation may ensure the best quality of coffee and increase the economic benefits for the growers [24]. As Corsetti et al. [25] have mentioned, the microorganisms selected for starter cultures are expected to have certain characteristics, such as being nonpathogenic, nontoxigenic, and adaptable to the raw materials and process. They should also produce sensory quality, prolong shelf life, reduce the processing time, and repress the development of food-related pathogenic microorganisms. Only limited studies have been reported on the use of a starter culture for coffee fermentation. The first study, by Agate and Bhat [26], effectively introduced a coffee fermentation starter culture. This study demonstrated that the addition of a mixture of three Saccharomyces species (viz., S. marxianus, S. bayanus, and $S$. cerevisiae var. ellipsoideus) facilitated the fermentation process by quickening the degradation of the mucilage layer.

A study was also conducted on the microbial and physicochemical characteristics of coffee fermentation by inoculating pectinolytic microbes isolated from spontaneous fermentation (viz., Lactobacillus brevis L166, Erwinia herbicola $\mathrm{C} 26$, B. subtilis $\mathrm{C} 12$, and Kluyveromyces fragilis K211) [27]. However, the authors reported that the inoculation of the pectinolytic microbes did not speed up the degradation of the polysaccharide compounds or modify the organoleptic characteristics of the beverage. They suggested that it would be better to use lactic acid bacteria instead in order to remain as close as possible to natural fermentation.

Recently, coffee fermentation using aromatic yeasts to develop flavour has been studied during dry [28], semidry [28], and wet [29] processing. A large microbial diversity is usually observed in coffee fermentation; however, most of these indigenous microorganisms presumably do not have important characteristics for improving the final coffee product, and a few species were chosen based on their final impacts on the coffee's flavour and aroma. The microbial ecology of the indigenous yeasts from which starter cultures were selected is reported in Tables 3 and 4.

\section{Coffee Fermentation's Impacts on Flavour and Aroma}

4.1. The Positive Impact of Fermentation on Coffee Flavour and Aroma. Around the globe, coffee is popular as a nonalcoholic drink because of its pleasant aroma and refreshing flavours. Joët et al. [31] report that coffee beans themselves contain all the precursors required to provide the standard coffee flavour and aroma during roasting. However, the fermentation process can increase the diversity of coffee aroma and flavour compounds. As mentioned by Tressi [32] and Farah et al. [33], more than 700 volatile and nonvolatile compounds that contribute to coffee flavour have been identified. The coffee's species, variety, geographic origin, and level of roasting determine the constitution and quantity of the flavour resulting from these compounds [34]. A supporting report indicates that factors during the preharvest and postharvest processes also critically affect the coffee aroma [35].

During coffee fermentation, microorganisms produce diverse metabolites. Microbial activity and the extent of fermentation determine the concentrations of free sugars (e.g., glucose and fructose) and free amino acids that continue to surround the bean and subsequently contribute to the production of Maillard compounds and volatiles during the roasting process [36]. Pederson and Breed [37] summarized early studies on the implication that fermentation improves coffee quality. Wet-processed coffee has superior aroma qualities to dry-processed coffee because of the aromatic compounds produced during the removal of the mucilage layer in wet processing [38]. The selection of appropriate microorganisms that have a positive impact on coffee flavour and aroma during fermentation is critical, and the fermentation process should be controlled to achieve this positive impact.

\subsection{The Negative Impact of Fermentation on Coffee Flavour} and Aroma. The major challenge in coffee fermentation, according to several studies, is the difficulty of controlling the process. Overfermentation is one of several dilemmas described by coffee farmers and scientists [39-41]. The fermentation process must be well controlled to ensure the development of beneficial microorganisms that produce a high-quality beverage with a good aroma. When fermentation fails, it results in the development of spoilage microorganisms that adversely affect the coffee's aroma and flavour. Coffee beans resulting from such fermentations are often referred to as "stinkers" [42, 43]. Underfermented coffee beans contain residual mucilage and sugar that prevent drying and create a conducive environment for the development of spoilage bacteria and fungi. Overfermentation encourages the production of undesirable chemical compounds, notably propionic and butyric acids, which confer off-flavours, such as an onion taste [44-47]. Lopez et al. [41] report that these acids should not be present in a concentration greater than $1 \mathrm{mg} \cdot \mathrm{mL}^{-1}$. Species of the $B a$ cillus genus, especially $B$. megaterium, may be responsible for the propionic acid found in coffees processed via dry or natural processing [11].

As described by Silva et al. [11], propionic acid is detected in high concentrations only when the fermentation process proceeds for longer than its optimum duration. Enterobacteriaceae and acetic acid bacteria lead to the production of excessive acetic acid during prolonged fermentation in dry processing [11]. Bade-Wegner et al. [47] state that overfermentation may also produce shortchain fatty acids and their esters, such as 2-methyl butanoic acid ethyl ester, 3-methyl butanoic acid ethyl ester, and cyclohexanoic acid ethyl ester. These can be detrimental to coffee quality if they are present at concentrations higher than $1.8,13.9$, and $14 \mathrm{mg} \cdot \mathrm{kg}^{-1}$, respectively. Furthermore, the growth of filamentous fungi and mycotoxins, which can generate off-flavours, should be controlled by the management of the fermentation and drying processes [48-52]. 
TABLE 3: The list of developed culture and their characteristics and effect on coffee fermentation.

\begin{tabular}{lccc}
\hline Starter culture & Screening criteria & Effect on coffee quality & References \\
\hline $\begin{array}{l}\text { Saccharomyces cerevisiae, } \\
\text { Candida parapsilosis, } \\
\text { and Pichia guilliermondii }\end{array}$ & $\begin{array}{c}\text { Pectinolytic activity and production of } \\
\text { organic acids and volatile aroma } \\
\text { compounds }\end{array}$ & $\begin{array}{c}\text { Production of high-quality coffee } \\
\text { beverages with special aroma of } \\
\text { caramel, herbs, and fruits }\end{array}$ & $\begin{array}{c}\text { Silva et al. [15]; } \\
\text { Evangelista et al. [30]; } \\
\text { Evangelista et al. [28] }\end{array}$ \\
$\begin{array}{l}\text { Pichia fermentans and } \\
\text { Saccharomyces sp. }\end{array}$ & $\begin{array}{c}\text { Pectinolytic activity, growth capacity } \\
\text { under stress conditions, and production } \\
\text { of volatile aroma compounds }\end{array}$ & $\begin{array}{c}\text { Production of coffee beverages with } \\
\text { high sensory scores for fruity, buttery, } \\
\text { and fermented aroma }\end{array}$ & Pereira et al. [29] \\
\hline Pichia fermentans & $\begin{array}{c}\text { Pectinolytic activity, growth capacity } \\
\text { under stress conditions, and production } \\
\text { of volatile aroma compounds }\end{array}$ & $\begin{array}{c}\text { Production of high-quality coffee } \\
\text { beverages with intense perception of } \\
\text { "vanilla" tests and "floral" aroma }\end{array}$ & Pereira et al. [16] \\
\hline
\end{tabular}

TABle 4: Microbial ecology of yeasts and bacteria of coffee fermentation from which starter culture selected.

\begin{tabular}{|c|c|c|}
\hline Species identified & Selected species & Reference \\
\hline $\begin{array}{l}\text { Lactobacillus plantarum, L. brevis, Lactococcus lactis, Leuconostoc mesenteroides, Pichia } \\
\text { anomala, P. caribbica, Rhodotorula mucilaginosa, Saccharomyces sp., S. bayanus, S. } \\
\text { cerevisiae, Candida ernobii, } \\
\text { C. fukuyamaensis, C. membranifaciens, C. carpophila, Hanseniaspora uvarum, } \\
\text { Torulaspora delbrueckii, Arxula sp., Kloeckera sp., and Kluyveromyces sp. }\end{array}$ & Saccharomyces cerevisiae & $\begin{array}{l}\text { Vilela et al. [12]; } \\
\text { Silva et al. [15] }\end{array}$ \\
\hline $\begin{array}{l}\text { Debaryomyces hansenii, D. polymorphus, D. polymorphus, Pichia guilliermondii, } P . \\
\text { guilliermondii, } P \text {. burtonii, P. anomala, } P \text {. burtonii, P. sydowiorum, } \\
\text { P. subpelliculosa, Candida saitoana, C. fermentati, } \\
\text { C. membranifaciens, Stephanoascus smithiae, Saccharomyces cerevisiae, Arxula } \\
\text { adeninivorans, and A. adeninivorans }\end{array}$ & Pichia guilliermondii & $\begin{array}{l}\text { Silva et al. [11]; } \\
\text { Silva et al. [15] }\end{array}$ \\
\hline $\begin{array}{l}\text { Pichia fermentans, } P \text {. guilliermondii, } P \text {. caribbica, Hanseniaspora opuntiae, Candida } \\
\text { glabrata, C. quercitrusa, and Saccharomyces sp. }\end{array}$ & $\begin{array}{l}\text { Pichia fermentans } \\
\text { and Saccharomyces sp. }\end{array}$ & $\begin{array}{l}\text { Pereira et al. [29]; } \\
\text { Pereira et al. [16] }\end{array}$ \\
\hline
\end{tabular}

\section{Green Coffee Bean Fermentation with Selected Microorganisms and Its Future Prospects}

A study was conducted by Kwak et al. [53] on the effect of the yeast fermentation of green coffee beans on their antioxidant activity and consumer acceptability. They reported that $24 \mathrm{~h}$ yeast fermentation induced a notable increase in antioxidant activity and total polyphenol and flavonoid contents. The consumer acceptance of the fermented coffee beans was slightly lower than that of the controls (nonfermented), with the exception of one fermented coffee beans (fermented with Saccharomyces species), which gained approximately $39.4 \%$ of consumers' preference over the controls [53].

Rhizopus oligosporus is a common fungal species widely used as a starter culture in fermented foods, such as soy tempeh (a traditional fermented soybean product). During fermentation by $R$. oligosporus, extracellular enzymes, such as proteases [54], and polysaccharide-degrading enzymes, such as xylanase, polygalacturonase, cellulase, arabinase, b-Dglucosidase, and a-D galactosidase [55], are secreted. A study was conducted on the effect of the solid-state fermentation of green coffee beans by $R$. oligosporus on their volatile and nonvolatile profile. As reported by Lee et al. [56], during fermentation, some volatiles were broken down, while the production of others could be correlated with the metabolism of aroma precursors by $R$. oligosporus. Fermentation with $R$. oligosporus significantly improved the compositions of the aroma precursors in green coffee beans, and these compounds are responsible for the production of potent classes of odorants (pyrazines, thiols, furanones, and guaiacols) that give rise to the characteristic coffee aroma during roasting [56].

Coffee enjoys wide global acceptance, and small improvements in coffee quality can make a significant difference and expand market opportunity. Because green coffee beans are used for fermentation instead of parchment coffee (with mucilage), this can be done by coffee-processing companies. However, the isolation and identification of microorganisms that significantly impact coffee sensory quality should be further investigated for the development of a starter culture. Future research may also investigate the commercialization of the aroma and flavour modulation of green coffee beans via fermentation.

\section{Conclusion}

Fermentation is crucial in coffee processing, not only to remove mucilage, but also, if well controlled, to create essential sensory quality characteristics. However, it has a disadvantage that if fermentation proceeds beyond the recommended time, microorganisms can also reduce the quality by creating off-flavours and undesirable characteristics. Of the diverse microflora found in natural coffee fermentation, a few may be selected for use as a starter culture. However, the potential use of starter cultures for coffee fermentation is not yet well studied. Most microorganisms isolated from spontaneous coffee fermentation lack attributes for improving coffee's sensory quality. The 
selection of food-grade microorganisms and their use in fermenting green coffee beans require further research. This review provides precise information about the role of microorganisms in coffee fermentation and their impact on coffee flavour and aroma. Other molecular sciences can contribute to an understanding of the chemical compounds produced during fermentation and their impact on coffee quality, leading to the availability of more credible and advanced information. Integrating multidisciplinary research will be helpful in more detailed studies.

\section{Conflicts of Interest}

The authors declare that they have no conflicts of interest.

\section{Acknowledgments}

This study was supported by 2018 research grant from the Kangwon National University (no. 520180086).

\section{References}

[1] International Coffee Organization (ICO), Monthly Coffee Market Report (2017/18), International Coffee Organization (ICO), London, UK, 2017, http://www.ico.org/MarketReport-17-18-e.asp.

[2] J. H. S. Taveira, F. M. Borém, L. P. Figueiredo et al., "Potential markers of coffee genotypes grown in different Brazilian regions: a metabolomics approach," Food Research International, vol. 61, pp. 75-82, 2014.

[3] D. Selmar, G. Bytof, S. E. Knopp, and B. Breitenstein, "Germination of coffee seeds and its significance for coffee quality," Plant Biology, vol. 8, no. 2, pp. 260-264, 2006.

[4] V. Leloup, C. Gancel, R. Liardon, A. Rytz, and A. Pithon, "Impact of wet and dry process on green coffee composition and sensory characteristics," in Proceedings of ASIC 2004-20th International Conference on Coffee Science, vol. 20, Bangalore, India, October 2004.

[5] G. Bytof, S. E. Knopp, P. Schieberle, I. Teutsch, and D. Selmar, "Influence of processing on the generation of $\gamma$-aminobutyric acid in green coffee beans," European Food Research Technology, vol. 220, no. 3-4, pp. 245-250, 2005.

[6] G. Bytof, S. E. Knopp, D. Kramer et al., "Transient occurrence of seed germination processes during coffee post-harvest treatment," Annals of Botany, vol. 100, no. 1, pp. 61-66, 2007.

[7] R. F. Schwan and G. H. Fleet, Cocoa and Coffee Fermentations, CRC Press, Boca Raton, FL, USA, 2014.

[8] P. Vaast, B. Bertrand, J. J. Perriot, B. Guyot, and M. Genard, "Fruit thinning and shade improve bean characteristics and beverage quality of coffee (Coffea arabica L.) under optimal conditions," Journal of the Science of Food and Agriculture, vol. 86, no. 2, pp. 197-204, 2006.

[9] C. Silva, "Microbial activity during coffee fermentation," in Cocoa and Coffee Fermentations, p. 368423, CRC Press, Boca Raton, FL, USA, 2014.

[10] P. S. Murthy and M. M. Naidu, "Sustainable management of coffee industry by-products and value addition: a review," Resources, Conservation and recycling, vol. 66, pp. 45-58, 2012.

[11] C. F. Silva, L. R. Batista, L. M. Abreu, E. S. Dias, and R. F. Schwan, "Succession of bacterial and fungal communities during natural coffee (Coffea arabica) fermentation," Food Microbiology, vol. 25, no. 8, pp. 951-957, 2008.
[12] D. M. Vilela, G. V. D. M. Pereira, C. F. Silva, L. R. Batista, and R. F. Schwan, "Molecular ecology and polyphasic characterization of the microbiota associated with semi-dry processed coffee (Coffea arabica L.)," Food Microbiology, vol. 27, no. 8, pp. 1128-1135, 2010.

[13] R. D. De Castro and P. Marraccini, "Cytology, biochemistry and molecular changes during coffee fruit development," Brazil Journal of Plant Physiology, vol. 18, no. 1, pp. 175-199, 2006.

[14] H. D. Belitz, W. Grosch, and P. Schieberle, "Coffee, tea, cocoa," in Food Chemistry, pp. 938-970, Springer, Berlin, Germany, 2009.

[15] C. F. Silva, D. M. Vilela, C. de Souza Cordeiro, W. F. Duarte, D. R. Dias, and R. F. Schwan, "Evaluation of a potential starter culture for enhance quality of coffee fermentation," World Journal of Microbiology and Biotechnology, vol. 29, no. 2, pp. 235-247, 2013.

[16] G. V. M. Pereira, V. T. Soccol, A. Pandey et al., "Isolation, selection and evaluation of yeasts for use in fermentation of coffee beans by the wet process," International Journal of Food and Microbiology, vol. 188, pp. 60-66, 2014.

[17] C. F. Silva, R. F. Schwan, E. S. Dias, and A. E. Wheals, "Microbial diversity during maturation and natural processing of coffee cherries of Coffea arabica in Brazil," International Journal of Food and Microbiology, vol. 60, pp. 251-260, 2000.

[18] M. P. Coughlan and F. Mayer, "The cellulose-decomposing bacteria and their enzymes systems," in The Prokaryotes, pp. 460-516, Springer, Berlin, Germany, 1991.

[19] B. L. Cantarel, P. M. Coutinho, C. Rancurel, T. Bernard, V. Lombard, and B. Henrissat, "The carbohydrate-active enzymes database (CAZy): an expert resource for glycogenomics," Nucleic Acids Research, vol. 37, no. 1, pp. 233-238, 2008.

[20] D. R. Kashyap, P. K. Vohra, S. Chopra, and R. Tewari, "Applications of pectinases in the commercial sector: a review," Bioresource and Technology, vol. 77, no. 3, pp. 215-227, 2001.

[21] D. B. Pedrolli, A. C. Monteiro, E. Gomes, and E. C. Carmona, "Pectin and pectinases: production, characterization and industrial application of microbial pectinolytic enzymes," Open Biotechnology Journal, vol. 3, no. 1, pp. 9-18, 2009.

[22] K. H. Steinkraus, Industrialization of Indigenous Fermented Foods, CRC Press, Boca Raton, FL, USA, 2004.

[23] R. F. Schwan, G. V. M. Pereira, and G. H. Fleet, "Microbial activities during cocoa fermentation," in Cocoa and Coffee Fermentations, R. F. Schwan and G. H. Fleet, Eds., pp. 129192, CRC Press, Boca Raton, FL, USA, 2014.

[24] G. Vinícius de Melo Pereira, V. T. Soccol, S. K. Brar, E. Neto, and C. R. Soccol, "Microbial ecology and starter culture technology in coffee processing," Critical Reviews in Food Science and Nutrition, vol. 57, no. 13, pp. 2775-2788, 2017.

[25] A. Corsetti, G. Perpetuini, M. Schirone, R. Tofalo, and G. Suzzi, "Application of starter cultures to table olive fermentation: an overview on the experimental studies," Frontiers in Microbiology, vol. 3, p. 248, 2012.

[26] A. D. Agate and J. V. Bhat, "Role of pectinolytic yeasts in the degradation of mucilage layer of Coffea robusta cherries," Applied Microbiology, vol. 14, no. 12, pp. 256260, 1966.

[27] S. Avallone, J. M. Brillouet, B. Guyot, E. Olguin, and J. P. Guiraud, "Involvement of pectolytic microorganisms in coffee fermentation," International Journal of Food Science and Technology, vol. 37, no. 2, pp. 191-198, 2002. 
[28] S. R. Evangelista, M. G. P. C. Miguel, C. S. Cordeiro, C. F. Silva, A. C. M. Pinheiro, and R. F. Schwan, "Inoculation of starter cultures in a semi-dry coffee (Coffea arabica) fermentation process," Food Microbiology, vol. 44, pp. 87-95, $2014 \mathrm{~b}$.

[29] G. V. M. Pereira, E. Neto, V. T. Soccol, A. B. P. Medeiros, A. L. Woiciechowski, and C. R. Soccol, "Conducting starter culture-controlled fermentations of coffee beans during onfarm wet processing: growth, metabolic analyses and sensorial effects," Food Research International, vol. 75, pp. 348-356, 2015.

[30] S. R. Evangelista, C. F. Silva, M. G. P. da Cruz Miguel et al., "Improvement of coffee beverage quality by using selected yeasts strains during the fermentation in dry process," Food Research International, vol. 61, pp. 183-195, 2014.

[31] T. Joët, A. Laffargue, F. Descroix et al., "Influence of environmental factors, wet processing and their interactions on the biochemical composition of green Arabica coffee beans," Food Chemistry, vol. 118, no. 3, pp. 693-701, 2010.

[32] R. Tressi, "Formation of flavor components in roasted coffee," in Thermal Generation of Aromas, pp. 285-301, ACS, Washington, DC, USA, 1989.

[33] A. Farah, A. C. Monteiro, V. Calado, A. S. Franca, and L. C. Trugo, "Correlation between cup quality and chemical attributes of Brazilian coffee," Food Chemistry, vol. 98, no. 2, pp. 373-380, 2006.

[34] J. Baggenstoss, L. Poisson, R. Kaegi, R. Perren, and F. Escher, "Coffee roasting and aroma formation: application of different time-temperature conditions," Journal of Agricultural and Food Chemistry, vol. 56, no. 14, pp. 5836-5846, 2008.

[35] W. B. Sunarharum, D. J. Williams, and H. E. Smyth, "Complexity of coffee flavor: a compositional and sensory perspective," Food Research International, vol. 62, pp. 315325, 2014.

[36] C. A. B. De Maria, L. C. Trugo, F. R. Aquino Neto, R. F. A. Moreira, and C. S. Alviano, "Composition of green coffee water-soluble fractions and identification of volatiles formed during roasting," Food Chemistry, vol. 55, no. 3, pp. 203-207, 1996.

[37] C. S. Pederson and R. S. Breed, "Fermentation of coffee," Food Research, vol. 11, pp. 99-106, 1945.

[38] O. Gonzalez-Rios, M. L. Suarez-Quiroz, R. Boulanger et al., "Impact of "ecological" post-harvest processing on the volatile fraction of coffee beans: I. Green coffee," Journal of Food Composition and Analysis, vol. 20, no. 3-4, pp. 289-296, 2007.

[39] S. C. Jackels and C. F. Jackels, "Characterization of the coffee mucilage fermentation process using chemical indicators: a field study in Nicaragua," Journal of Food Science, vol. 70, no. 5, pp. 321-325, 2005.

[40] G. I. Puerta-Quintero, "Strategies to guarantee the quality of the beverage in Colombian coffees," in Proceedings of 19th International Scientific Colloquium on Coffee, Trieste, Italy, January 2001.

[41] I. López-Galilea, N. Fournier, C. Cid, and E. Guichard, "Changes in headspace volatile concentrations of coffee brews caused by the roasting process and the brewing procedure," Journal of Agricultural and Food Chemistry, vol. 54, no. 22, pp. 8560-8566, 2006.

[42] H. A. Frank, N. A. Lum, and A. S. D. Cruz, "Bacteria responsible for mucilage-layer decomposition in Kona coffee cherries," Applied Microbialogy, vol. 13, no. 2, pp. 201-207, 1965.

[43] R. O. Arunga, "Coffee," in Fermented Foods, A. H. Rose, Ed., pp. 259-274, Academic Press, London, UK, 1982.
[44] H. P. Krug, "Cafés Duros III. Relação entre a porcentagem de microrganismos e qualidade do café," Revista do Instituto do Café, São Paulo, vol. 27, pp. 1827-1831, 1940.

[45] L. C. Mônaco, "Armazenamento do café. Boletim da Superintendência dos Serviços do," Café. São Paulo, vol. 36, pp. 15-16, 1961.

[46] H. V. Amorim and V. L. Amorim, "Coffee enzymes and coffee quality," in Enzymes in Food and Beverage Processing, R. L. Ory and A. J. Angelo, Eds., pp. 27-55, Journal of American Chemical Society, Washington, DC, USA, 1977.

[47] H. Bade-Wegner, I. Bendig, W. Holscher, and R. Wollmann, "Volatile compounds associated with the over-fermented flavour defect," in Proceedings of 17th International Scientific Colloqium on Coffee, pp. 176-182, Nairobi, Kenya, January 1997.

[48] L. R. Batista, S. M. Chalfoun, and G. Prado, "Identificação de espécies toxigenicas de Aspergillus associadas aos grãos de café armazenados," Revista Brasileira de Armazenamento, vol. 3, pp. 11-16, 2001.

[49] L. R. Batista, S. M. Chalfoun, C. F. Silva, M. Cirillo, E. A. Varga, and R. F. Schwan, "Ochratoxin A in coffee beans (Coffea arabica L.) processed by dry and wet methods," Food Control, vol. 20, no. 9, pp. 784-790, 2009.

[50] M. H. Taniwaki, J. I. Pitt, A. A. Teixeira, and B. T. Iamanaka, "The source of ochratoxin A in Brazilian coffee and its formation in relation to processing methods," International Journal of Food Microbiology, vol. 82, no. 2, pp. 173-179, 2003.

[51] M. H. Taniwaki, B. T. Iamanaka, and M. H. P. Fungaro, "Toxigenic fungi and mycotoxins in coffee," in Cocoa and Coffee Fermentation, R. F. Schwan and G. H. Fleet, Eds., CRC Taylor \& Francis, Boca Raton, FL, USA, 2014.

[52] M. L. Suárez-Quiroz, O. González-Rios, M. Barel, B. Guyot, S. Schorr- Galindo, and J. P. Guiraud, "Study of ochratoxin A producing strains in coffee processing," International Journal of Food Science and Technology, vol. 39, no. 5, pp. 501-507, 2004.

[53] H. S. Kwak, Y. Jeong, and M. Kim, "Effect of yeast fermentation of green coffee beans on antioxidant activity and consumer acceptability," Journal of Food Quality, vol. 2018, Article ID 5967130, 8 pages, 2018.

[54] T. Handoyo and N. Morita, "Structural and functional properties of fermented soybean (tempeh) by using Rhizopus oligosporus," International Journal of Food Properties, vol. 9, no. 2, pp. 347-355, 2006.

[55] J. C. De Reu, V. A. Linssen, F. M. Rombouts, and M. R. Nout, "Consistency, polysaccharidase activities and non starch polysaccharides content of soya beans during tempe fermentation," Journal of the Science of Food and Agriculture, vol. 73, no. 3, pp. 357-363, 1997.

[56] L. W. Lee, M. W. Cheong, P. Curran, B. Yu, and S. Q. Liu, "Modulation of coffee aroma via the fermentation of green coffee beans with Rhizopus oligosporus: I. Green coffee," Food Chemistry, vol. 211, pp. 916-924, 2016. 


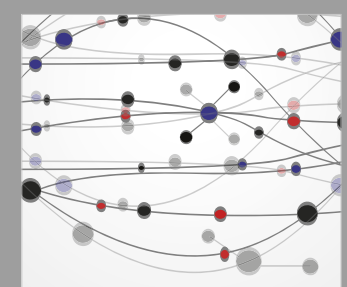

The Scientific World Journal
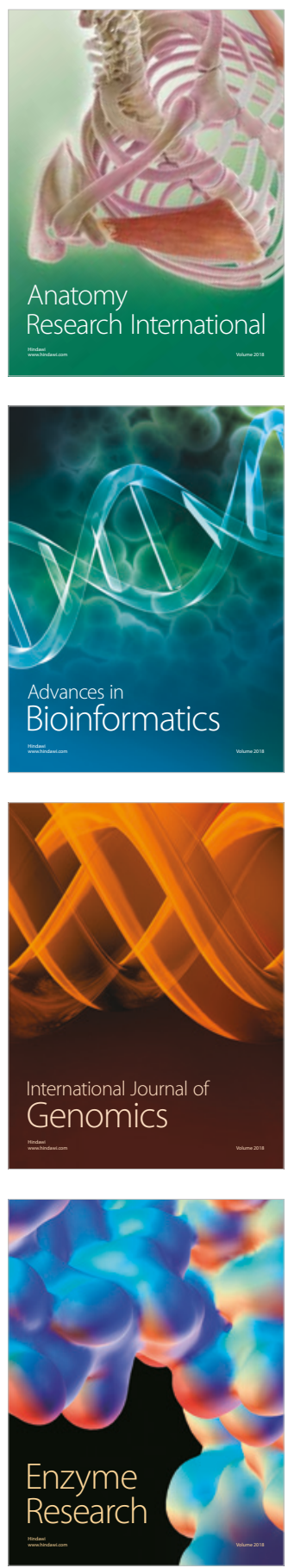
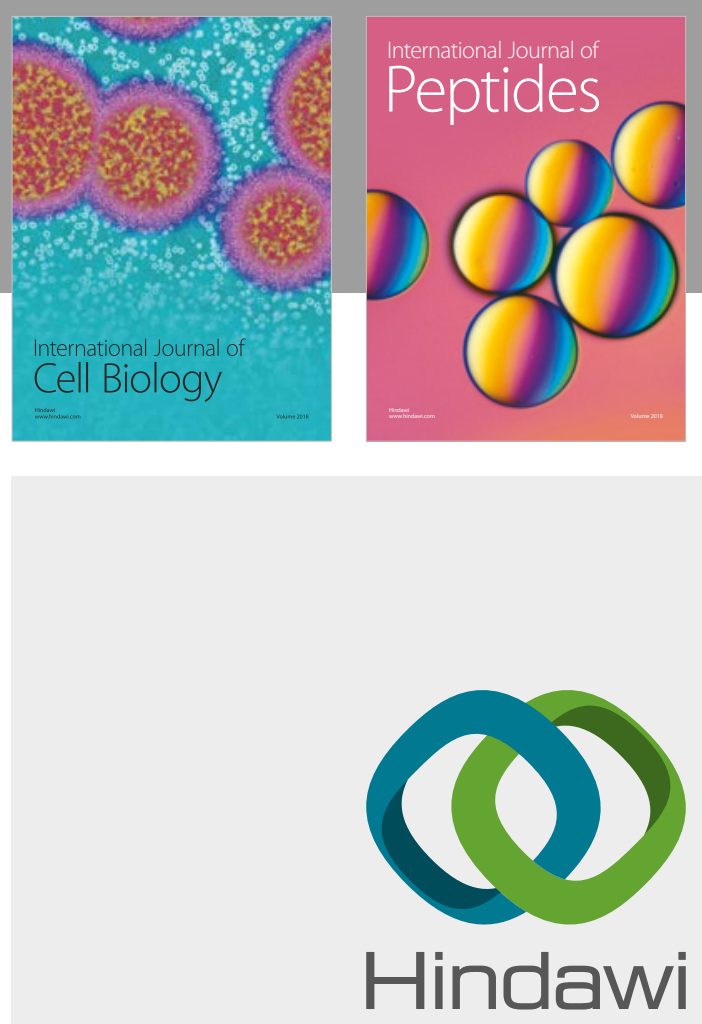

Submit your manuscripts at

www.hindawi.com
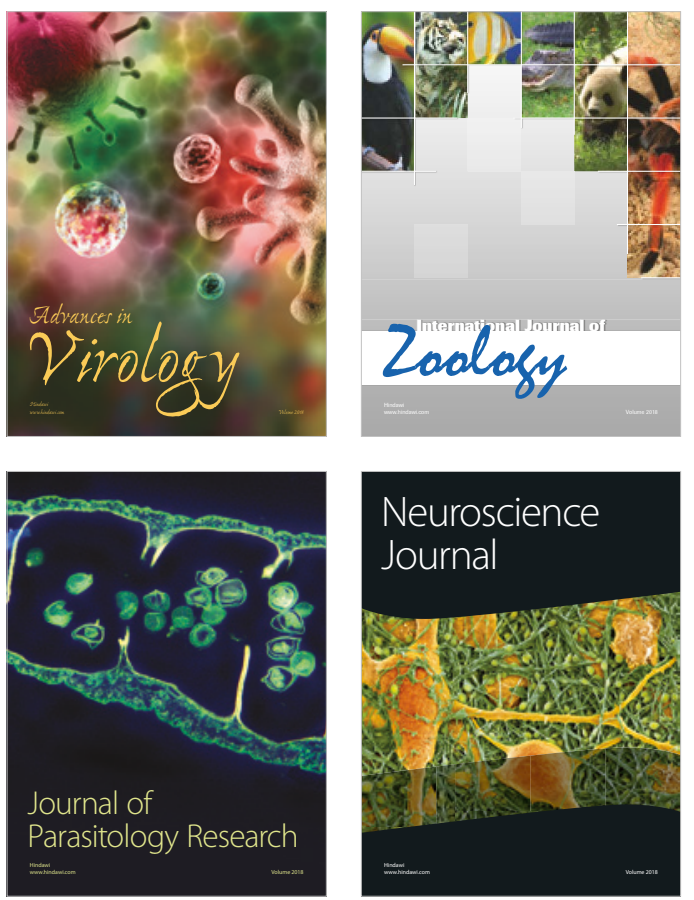
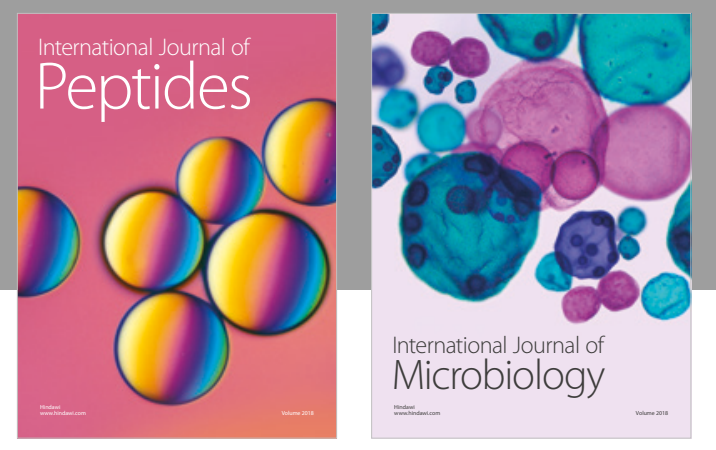

nternational Journal of Microbiology
Journal of
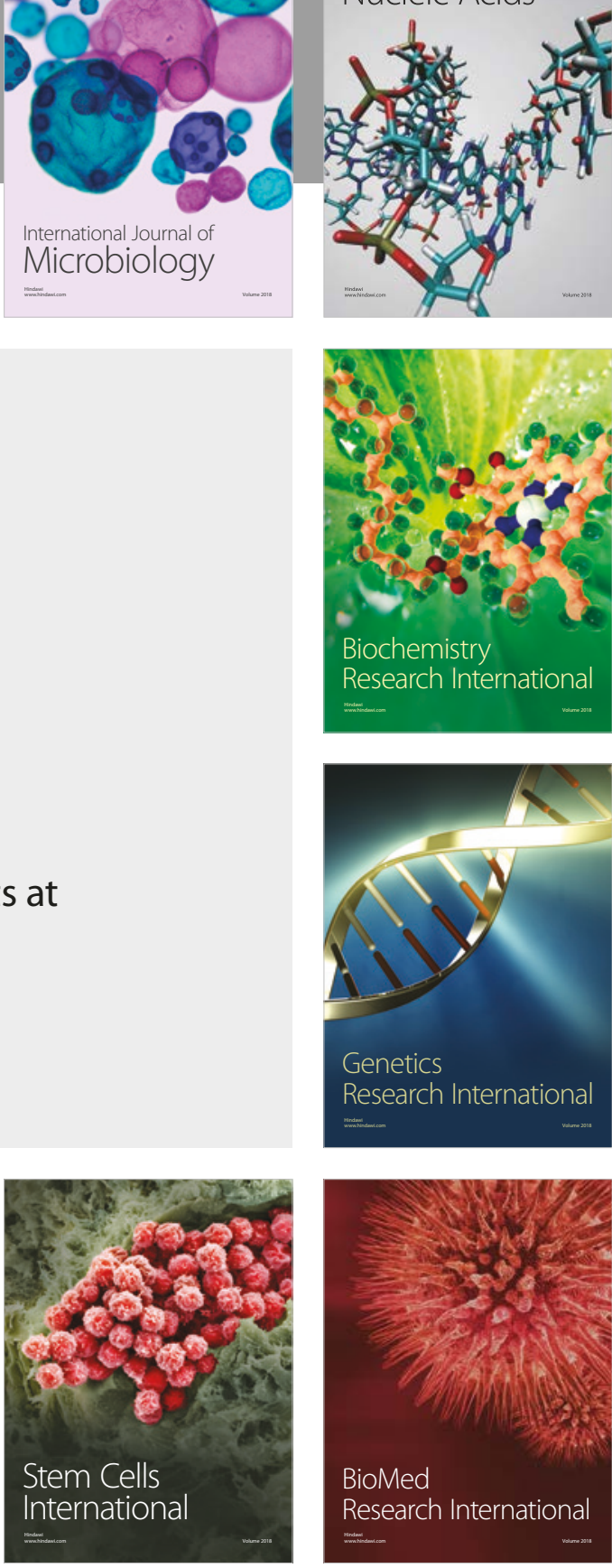
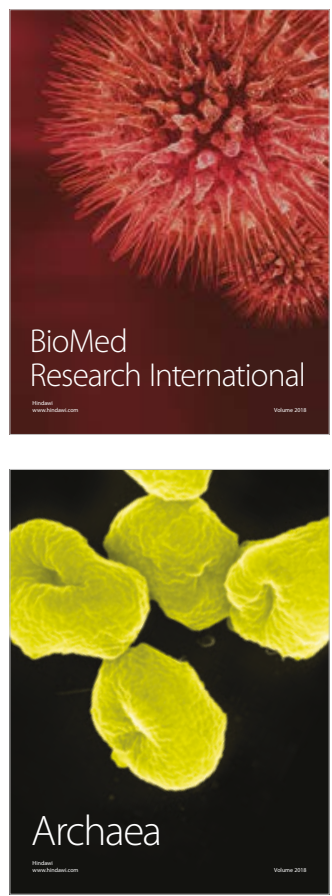